\title{
Evaluasi Perancangan Sistem Informasi Akuntansi Simpan Pinjam Di Koperasi Dian Lestari Jakarta Timur
}

\author{
Wening Estiningsih, Heri Nurranto* \\ Universitas Indraprasta PGRI, Jakarta \\ "Correspondence email: heri.nurranto@gmail.com
}

\begin{abstract}
Abstrak. Tujuan penelitian mengetahui sistem informasi akuntansi simpan pinjam pada Koperasi Dian Lestari Jakarta Timur. Dalam analisis lebih lanjut penelitian ini menganalisis dan merancang sistem informasi akuntasi yang dapat diterapkan di koperasi tersebut. Data dikumpulkan melalui metode wawancara, observasi dan data sekunder yang berupa dokumen. Teknik analisis data menggunakan analisis data kualitatif dengan pendekatan induktif. Hasil penelitian menunjukkan bahwa sistem akuntansi simpan pinjam di Koperasi Dian Lestari Jakarta terdapat beberapa kekurangan dan kelemahan, yaitu catatan-catatan dilakukan secara manual, koordinasi laporan yang kurang antar perangkat dalam koperasi serta tingkat akurasi pelaporan atau pencatatan yang masih kurang. Perancangan sistem informasi akuntansi simpan pinjam yang dusulkan oleh peneliti dirancang untuk mampu mengatasi kelemahan atau kekurangan yang ada disesuaikan dengan kebutuhan koperasi.
\end{abstract}

Kata kunci: Koperasi; Simpan Pinjam; Sistem Informasi Akuntansi

Abstract. The research objective is to find out the accounting information system at Dian Lestari savings and loan Cooperative, East Jakarta. In further analysis, this study analyzes and designs an accounting information system that can be applied in the cooperative. Data were collected through interviews, observation and secondary data in the form of documents. Data analysis techniques using qualitative data analysis with an inductive approach. The results showed that the savings and loan accounting system at the Dian Lestari Cooperative had several shortcomings and weaknesses, namely manual records, inadequate reporting coordination between devices in the cooperative and the lack of accuracy in reporting or recording. The design of the savings and loan accounting information system proposed by the researcher is designed to be able to overcome existing weaknesses or deficiencies tailored to the needs of the cooperative

Keywords: Cooperative; Savings and Loan; Accounting Information System

\section{PENDAHULUAN}

Bentuk koperasi di Indonesia yang sangat familiar adalah koperasi simpan pinjam. Seperti koperasi pada umumnya, koperasi simpan pinjam memiliki sumber modal utama yang berasal dari simpanan anggota. Dari simpanan anggota ini, koperasi berusaha untuk menyalurkannya kembali kepada anggota sebagai pinjaman kepada anggota. Maka, secara singkat fungsi koperasi simpan pinjam adalah mengelola dana yang berasal dari simpanan anggota dan mengalokasikanya sebagai pinjaman atau kredit kepada anggota dengan besaran bagi hasil yang disepakati dalam koperasi.

Dalam menjamin kelancaran administrasi dalam koperasi, khususnya simpan pinjam dibutuhkan pengetahuan dan ketelitian dalam pembukuan atau administrasi. Pada pengolahan akuntansi, untuk menghindari kesalahan penulisan ataupun efektifitas waktu, diperlukan sistem akuntansi simpan pinjam yang baik. Diperlukan perubahan yang dapat meningkatkan keefektifan dalam penerapan sebuah sistem. Perubahan yang paling tepat dilakukan adalah penerapan sistem informasi akuntansi secara komputerisasi.

Pada penelitian sebelumnya (Ningsih et al., 2020), dengan perubahan sistem pinjaman yang masih manual ke dalam sistem yang terkomputerisasi sehingga mengurangi kesalahan-kesalahan yang terjadi akibat human error dan berusaha menghindari data yang hilang atau terselip. Maka, sistem informasi akuntansi penting dilaksanakan karena penerapan sistem informasi pengolahan data simpan pinjam koperasi secara komputerisasi dapat meningkatkan efiseinsi, efektifitas, transparansi dan akuntabilitas dalam kegiatan koperasi. Hal ini sejalan dengan hasil penelitian sebelumnya pada Koperasi keluarga Besar PT. Semen Padang (Puspita, 2018), bahwa 1) sebaiknya pengolahaan data menggunakan teknologi informasi, agar lebih efisien dan pihak manajemen dapat mengambil keputusan dengan cepat, tepat dan akurat, 2) sebaiknya dalam pengolahan data transaksi di unit toserba menggunakan program aplikasi dapat mengolah dan menghasilkan informasi yang benar dan tepat waktu sesuai dengan kebutuhan, dimana pengarsipan pada unit toserba yang tadinya manual diganti dengan database komputerisasi.

Aplikasi simpan pinjam yang digunakan akan dilengkapi dengan pengolahan akuntansi dan laporan Sisa Hasil Usaha (SHU). Sehingga dengan menggunakan sistem informasi, pengolahan data dan pembuatan laporan menjadi lebih mudah, cepat dan penyajian data yang lebih akurat.

Koperasi adalah badan usaha yang beranggotakan orang-seoarng atau badan hukum koperasi dengan melandaskan kegiatannya berdasarkan prinsip koperasi sekaligus sebagai gerakan ekonomi rakyat yang berdasar atas asas kekeluargaaan (UU No 25 Tahun 1992, 1992). 
Definisi lainnya menurut Hans H Moenker (Gayatri dan Nurranto, 2019:22), koperasi adalah organisasi ekonomi yang anggotanya memiliki sekurang-kurangnya satu kepentingan ekonomi yang sama, bermotivasi swadaya dalam perusahaan yang dibiayai dan diawasi dengan sasaran meningkatkan kemajuan perusahaan rumah tangga anggota.

Dalam perkembangannya, di Indonesia muncul berbagai jenis koperasi, salah satunya adalah Koperasi Simpan Pinjam. Koperasi Simpan Pinjam adalah koperasi yang bergerak di bidang pemupukan simpanan dari anggotanya, untuk kemudian dipinjamkan kembali kepada para anggota yang memerlukan bantuan modal untuk usahanya (Gayatri dan Nurranto, 2019:38). Koperasi simpan pinjam didirikan untuk mendukung kepentingan anggota yang membutuhkan tambahan modal usaha dan kebutuhan finasial lainnya (Limbong, 2010:76).

Dalam manajemen koperasi, pengelolaan dalam koperasi dilakukan secara terbuka, terutama bagi aanggotanya. Keterbukaan dalam hal ini tidak berate bahwa semua informasi usaha, keuangan, organisasi dan ketatalaksanaan koperasi diungkapkan secara bebas. Keterbukaan koperasi menititberatkan pada pelaksanaan fungsi pertanggungjawaban pengurus koperasi yang diuraikan kepada anggota melalui rapat anggota (Limbong, 2010:150). Aspek keuangan merupakan bagian penting dalam pertanggungjawaban pengurus koperasi, karena permodalan koperasi pada prinsipnya berasal dari anggota untuk dialokasikan pada usaha koperasi.

Laporan keuangan dalam koperasi dapat dijadikan sebagai salah satu aspek keberasilan dan evaluasi kinerja koperasi. Secara terperinci tujuan laporan keuangan koperasi adalah 1) menilai pertanggungjawaban pengurus, 2) menilai prestasi pengurus, 3) menilai manfaat yang diberikan koperasi terhadap anggotanya, 4) menilai kondisi keuangan koperasi, dan 5) sebagai bahan pertimbangan untuk menentukan jumlah sumber daya serta jasa yang akan diberikan kepada koperasi (Limbong, 2010:152). Selain tujuan-tujuan tersebut, bahwa laporan keuangan koperasi akan berkaitan dengan akses para pengguna utama dalam koperasi yaitu anggota koperasi, pejabat koperasi, calon anggota koperasi, bank, kreditur serta kantor pajak. Semua pihak sebagai penguna laporan tersebut layak untuk menggunakanya sebagai acuan pertimbangan aktivitas, analisis resiko dan atau untuk kepentingan lainnya.

Langkah awal dalam menjalankan proses akuntansi adalah mengenali system informasi akuntansi yang diterapkan oleh perusahaan. Sistem informasitersebut meliputi sekumpulan sumber daya yang dirancang sedemikian rupa untuk mengubah data menjadi informasi. Dalam system informasi akuntansi, maka dibutuhkan seperangkat prosedur formal yang digunakan untuk mengumpulkan data dan mengolahnya menjadi informasi dan mendistribusikannya kepada pihak yang menggunakannya.

Sumber daya yang dimaksud dalam sistem informasi akuntansi meliputi sumber daya manusia, material, peralatan, kebijakan serta prosedur yang dihubungkan dalam satu rancangan yang akan berfungsi mengubah unit-unit data menjadi informasi akuntansi dan dirancang secara spesifik untuk organisasi, baik orhganisasi nirlaba maupun komersial.

Sistem informasi akuntansi adalah organisasi formulir, catatan dan laporan yang dikoordinasi sedemikian rupa untuk menyediakan informasi keuangan yang dibutuhkan oleh manajemen guna memudahkan pengelolaan perusahaan (Mulyadi, 2001:3). Sistem informasi akuntansi adalah suatu komponen organisasi yang mengumpulkan, menggolongkan, mengolah, menganalisa dan mengkomunikasikan informasi keuangan yang relevan untuk pengambilan keputusan kepada pihak-pihak luat, seperti inpeksi pajak, investor dan kreditur dan piihak-pihak dalam manajemen (Baridwan, 1996:4). Menurut George H Bodnar dan Wilkliam S Hopwood(Fauzi, 2017), sistem informasi akuntansi adalah kumpulan sumber daya seperti manusia dan peralatan yang diatur untuk mengubah data ekonomi menjadi informasi yang berguna.

Berdasarkan definisi-definisi tersebut maka dapat disimpulkan bahwa sistem informasi akuntasi memiliki manfaat sebagai terjalinnya komunikasi yang baik antara organisasi perusahaan dengan lingkungannya. Artinya bahwa informasi informasi dalam akuntansi ini akan dapat dipergunakan oleh internal maupun eksternal perusahaan untuk berbagai kebutuhan termasuk kebutuhan nilai ekonomis dalam perusahaan.

Koperasi sebagai bentuk badan usaha, secara mendasar tidak memiliki perbedaan dalam pelaporan keuangan, sehingga sistem informasi akuntasi juga penting dalam koperasi. Mendasarkan pada definisi sistem informasi akuntasi beserta manfaatnya maka, sistem informasi akuntansi koperasi adalah sistem yang mengolah data transaksi akuntansi dalam koperasi menjadi informasi keuangan yang bisa digunakan oleh pihak-pihak berkepentingan, yaitu anggota, pengurus, pengawas atau serta pihak eksternal koperasi yang berkepentingan.

Dalam observasi awal yang dilakukan peneliti, saat ini koperasi simpan pinjam di Indonesia lebih banyak menggunakan sistem pembukuan manual untuk pencatatan transaksinya, misalnya pencatatan transaksi di microsoft excel. Koperasi Dian Lestari Jakarta Timur adalah salah satu contoh koperasi simpan pinjam yang masih menggunakan pencatatan manual. Pencatatan manual dapat berdampak pada terjadinya kesalahan dalam sistem pencatatan, sehingga pencatatan manual belum efektif serta efisien. Hal ini dapat diilustrasikan bahwa, semakin tinggi transaksi dalam koperasi maka akan semakin banyak perhitungan atau administrasinya. Maka seperti diuraikan sebelumnya, penting bagi 
koperasi untuk melakukan pembukuan secara komputerisasi dan melaksanakan sistem informasi akuntansi. Uraian-uraian ini menjadi pendorong penulis untuk memberikan analisis perancangan sistem informasi akuntasi koperasi simpan pinjam di koperasi Dian Lestari Jakarta.

\section{METODE}

Metode penelitian yang digunakan dalam penelitian ini adalah metode pendekatan kualitatif deskriptif. Pendekatan kualitatif memiliki karakteristik latar alami, dimana penyelidikan kualitatif dilaksanakan di lingkungan alami tempat orang-orang berada, sehingga memungkinkan peneliti mengamati bagaimana orang-orang yang diteliti melakukan interaksi dan aktivitas rutinnya (Christine Daymon, Immy Holloway 2008). Penentuan sampel menggunakan metode purposive sampling yaitu teknik pengambilan sampel sumber data dengan pertimbangan tertentu (Sugiyono, 2010:300).

Dalam penelitian ini sampel yang digunakan adalah prosedur proses simpan pinjam berserta dokumen pendukung prosedur pada Koperasi Kredit Dian Lestari, Jakarta. Data diperoleh melalui metode wawancara terbuka dengan memilih informan sebagai sumber data yaitu Ibu Marini selaku pengurus Koperasi Kredit Dian Lestari. Data-data sekunder berupa data simpan pinjam dan dokumen-dokumen yang berkaitan dengan permasalahan yang diteliti. Tujuan penelitian ini adalah untuk mengetahui dan mengevaluasi sejauh mana sistem informasi akuntansi yang diterapakan di Koperasi Kredit Dian Lestari, Jakarta.

\section{HASIL DAN PEMBAHASAN}

Perancangan sistem informasi akuntansi simpan pinjam yang diusulkan peneliti menghasilkan beberapa file komputer yang nantinya dapat dicetak menjadi dokumen-dokumen. Sistem informasi akuntansi simpan pinjam ini menggunakan cara manual dalam mendistribusikan dokumen-dokumen, tetapi dalam mengolah data akuntansi dan membuat laporan-laporan, sistem informasi akuntansi yang diusulkan sudah memakai sistem yang terkomputerisasi.

\section{Dokumen dalam Sistem Akuntansi}

Dokumen yang digunakan dalam sistem usulan pada sistem akuntansi simpan pinjam di Koperasi Dian Lestari Jakarta adalah sebagai berikut :

a. Buku Anggota (BA)

Dokumen yang digunakan sebagai bukti simpanan dan pinjaman untuk anggota.

b. Slip Uang Masuk (SUM)

Slip uang masuk digunakan sebagai bukti setoran simapanan anggota untuk koperasi.

c. Surat Permohonan Pinjaman (SPP)

Dokumen yang digunakan sebagai formulir pengajuan pinjaman yang dilakukan anggota.

\section{d. Surat Perjanjian Pinjaman Anggota (SPPA)}

Dokumen ini digunakan sebagai surat perjanjian pinjaman antara anggota sebagai peminjam dan koperasi sebagai pemberi pinjaman.

e. Slip Uang Keluar (SUK)

Slip uang keluar digunakan sebagai bukti pinjaman anggota untuk koperasi.

\section{Prosedur Simpan Pinjam}

Berikut ini adalah prosedur simpan pinjam yang diusulkan pada Koperasi Dian Lestari Jakarta :

\section{Prosedur Simpanan}

Anggota memberikan buku anggota ke petugas koperasi. Petugas koperasi membuat slip uang masuk (SUM) 2 rangkap, menginput data simpanan pada komputer dan kemudian mencetak simpanan pada buku anggota.Kemudian slip uang masuk (SUM) 2 rangkap dan buku anggota diserahkan ke bendahara. Bendahara menandatangani buku anggota dan slip uang masuk (SUM) 2 rangkap, setelah itu buku anggota dan slip uang masuk 2 (SUM2) dikembalikan ke petugas koperasi sedangkan slip uang masuk 1 (SUM1) diarsip oleh bendahara sebagai bukti uang masuk. Petugas koperasi mengembalikan buku anggota yang sudah diparaf oleh bendahara ke anggota. Kemudian petugas koperasi mengarsip slip uang masuk 2 (SUM2) dalam arsip SUM.

\section{Prosedur Pinjaman}

Anggota membawa buku anggota ke koperasi dan menyerahkan ke petugas koperasi untuk pengajuan pinjaman. Petugas koperasi melakukan pengecekan buku anggota dengan memeriksa usia keanggotaan dan data pinjaman pada komputer. Apabila tidak memenuhi syarat, maka pengajuan ditolak dan buku anggota dikembalikan, sedangkan jika diterima maka anggota diberikan surat permohonan pinjaman. Anggota mengisi surat permohonan pinjaman dan mengembalikan ke petugas koperasi. Petugas koperasi memberikan surat permohonan pinjaman (SPP) dan buku anggota ke bagian pengurus. Bagian pengurus menganalisa pengajuan pinjaman jika diterima surat permohonan pinjaman ditandatangani dan jika di tolak buku anggota dikembalikan. Jika diterima petugas koperasi membuat surat perjanjian pinjaman anggota (SPPA) dan membuat slip uang keluar (SUK) 3 rangkap serta menginput pinjaman pada komputer dan mencetaknya pada buku anggota. Petugas koperasi menyerahkan surat perjanjian pinjaman anggota (SPPA),buku anggota dan slip uang keluar(SUK) untuk di tandatangani bendahara. Kemudian surat perjanjian pinjaman anggota (SPPA), buku anggota, slip uang keluar 2 (SUK2) dan slip uang keluar 3 (SUM3) dikembalikan ke petugas koperasi sedangkan slip uang keluar (SUK1) diarsip bendahara sebagai bukti uang keluar. Setelah ditandatangani oleh petugas koperasi, buku anggota dan surat perjanjian pinjaman anggota (SPPA) dikembalikan ke anggota dan 
meminta anggota untuk menandatangani SPPA. Anggota menandatangani SPPA dan mengembalikan ke petugas koperasi. Petugas koperasi mengarsip SPPA di arsip SPP dan SUK 2 di arsip pada arsip SUK, sedangkan SUK 3 diberikan kebagian pembukuan.

Diagram prosedur simpan pinjam yang diusulkan oleh peneliti diilustrasikan dalam flowchart simpanan dan pinjaman pada gambar 1 berikut ini.

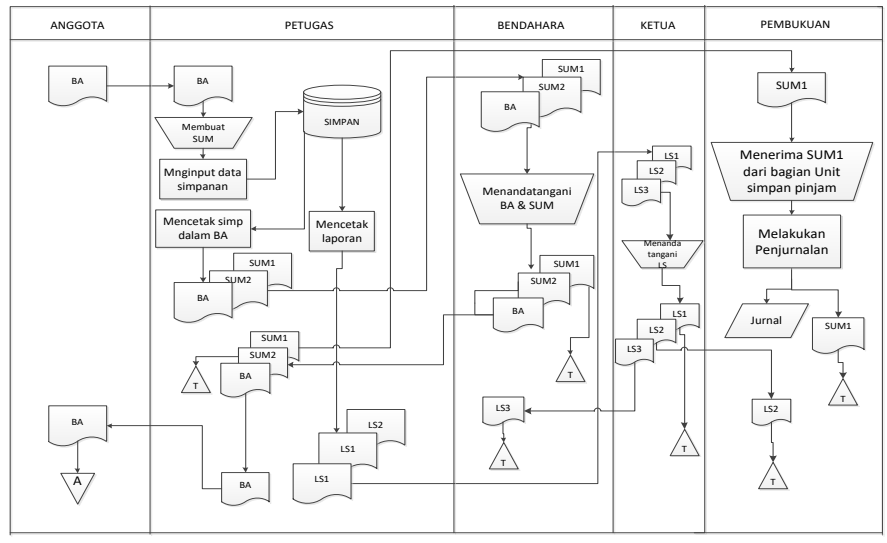

Gambar 1. Flowchart Simpanan Sistem Usulan

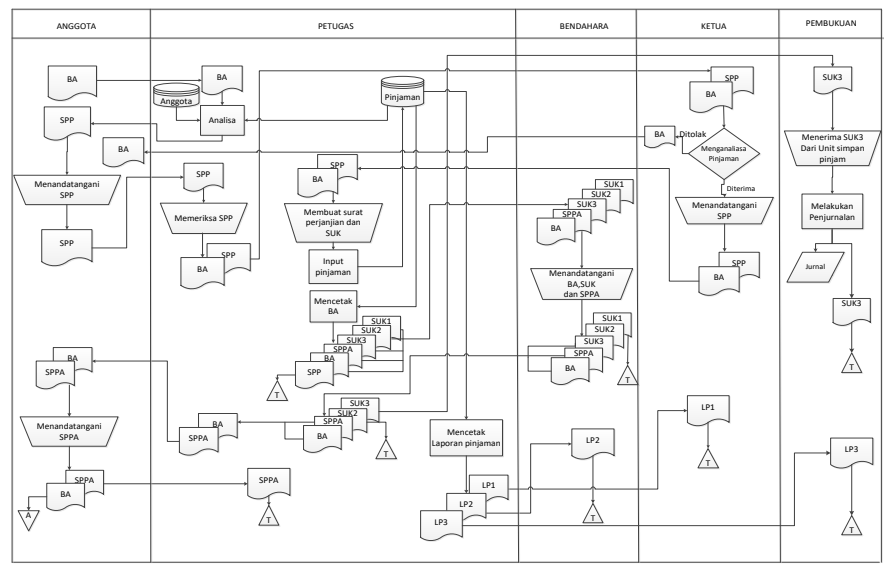

Gambar 2. Flowchart Pinjaman Sistem Usulan

\section{Keterangan:}

BA = Buku Anggota

SUM = Slip Uang Masuk

SPP = Surat Permohonan Pinjaman

SUK = Slip Uang Keluar

SPPA = Surat Perjanjian Pinjaman Anggota

LP $\quad=$ Laporan Pinjaman

LS = Laporan Simpanan

A $\quad=$ Pengarsipan oleh anggota

\section{Model logika dari sistem yang diusulkan}

Berikut ini adalah penjelasan dari model logika sistem yang diusulkan peneliti dalam data flow diagram.

\section{Diagram Konteks}

Pada saat melakukan simpanan, anggota membawa buku anggota bersama uang ke unit simpan pinjam, unit simpan pinjam membuat SUM dan melakukan penginputan data simpanan dan mencetak buku anggota atas simpanan, kemudian buku anggota dan SUM diberikan kebendahara bersama uang untuk di tandatangani dan buku anggota dikembalikan ke anggota. Saat melakukan pinjaman, unit simpan pinjam memberikan surat permohonan pinjaman untuk diisi anggota dan dikembalikan ke unit simpan pinjam beserta buku anggota, surat permohonan pinjaman dan buku anggota diberikan ke ketua untuk dipertimbangkan, ketika diterima surat permohonan ditandatangani kemudian unit simpan pinjam membuat SUK dan SPPA serta menginput dan mencetak pijaman pada buku anggota. Kemudian SUK,SPPA dan buku anggota dibawa ke bendahara untuk ditandatangani. Setelah ditandatangani SPPA dan buku anggota beserta uang diberikan ke anggota,anggota menandatangani SPPA dan mengembalikan ke unit simpan pinjam. Setelah transaksi simpan pinjam diolah ketua dan bendahara akan menerima laporan simpan pinjam dari unit simpan pinjam.

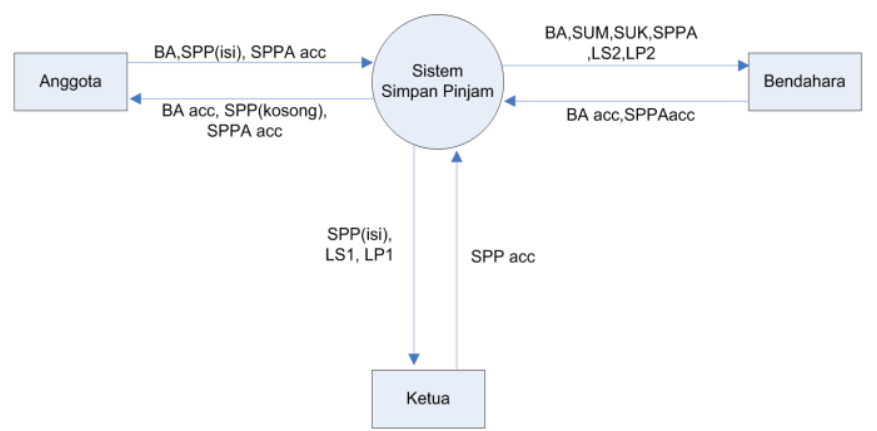

Gambar 3. Diagram Konteks

\section{Diagram Nol}

Pada proses pertama, anggota melakukan simpanan dengan menyerahkan buku anggota, kemudian unit simpan pinjam membuat SUM 3 (tiga) rangkap serta menginput dan mencetak simpanan pada buku anggota. Langkah selanjutnya adalah SUM 3 (tiga) rangkap dan buku anggota diserahkan ke bendahara dan ditandatangani. SUM2, SUM3 dan buku anggota selanjutnya dikembalikan ke unit simpan pinjam, kemudian buku anggota dikembalikan ke anggota, SUM3 diberikan kebagian pembukuan dan SUM2 diarsip dalam arsip SUM.

Pada proses kedua, proses pinjaman anggota diawali dengan membawa buku anggota ke unit simpan pinjam untuk mengajukan pinjaman. Unit memberikan surat permohonan untuk diisi, setelah itu surat permohonan dikembalikan ke unit simpan pinjam untuk diserahkan ke ketua koperasi beserta buku anggota. Setelah permohonan disetujui dan ditandatangani, kemudian dikembalikan ke unit simpan pinjam untuk membuat SUK 3 (tiga) rangkap dan SPPA serta menginput serta mencetak data pinjaman dalam buku anggota. 
Buku anggota, surat perjanjian pinjaman anggota beserta slip uang keluar (SUK) diserahkan ke bagian bendahara untuk ditandatangani. Setelah buku anggota, surat perjanjian pinjaman anggota dan SUK ditandatangani dan dikembalikan ke unit simpan pinjam, kemudian dokumen tersebut dikembalikan ke anggota, dan anggota mengembalikan surat perjanjian pinjaman anggota yang sudah ditandatangani ke bagian simpan pinjam. Proses selanjutnya adalah unit mengarsip surat perjanjian pinjaman anggota dalanm arsip SPPA dan SUK2 dalam arsip SUK, sedangkan SUK3 diberikan kebagian pembukuan.

Proses pembuatan laporan diawali dengan mengambil data anggota, data simpanan dan data pinjaman pada tiap form dan unit simpan pinjam memprosesnya menjadi laporan simpanan dan laporan pinjaman yang selanjutnya diserahkan ke ketua dan bendahara.

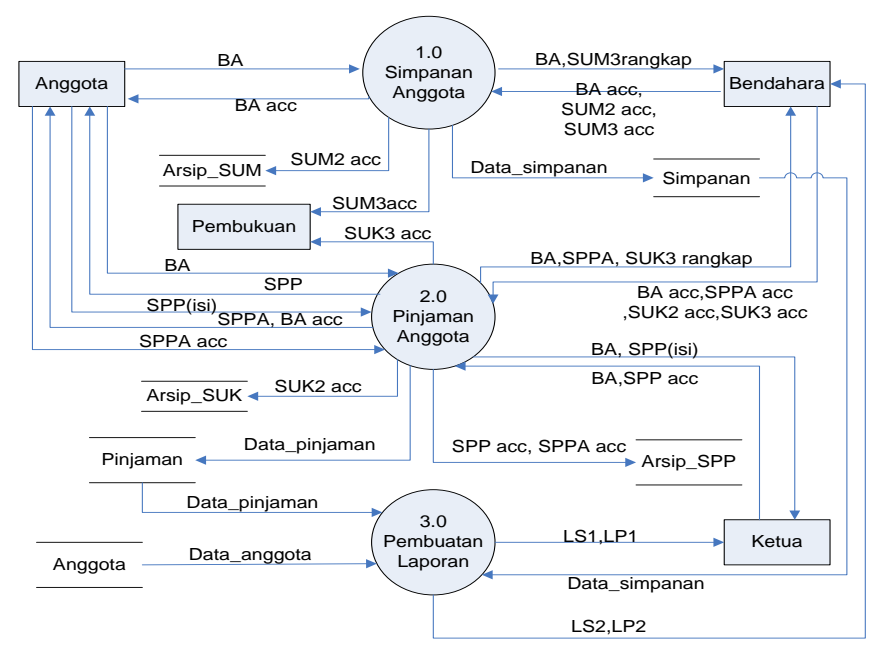

Gambar 4. Diagram Nol

\section{Diagram Level}

\section{DFD Level 1 proses 1}

Pada proses 1 anggota melakukan simpanan dengan membawa buku anggota (BA) dan kemudian petugas membuat SUM sebagai bukti simpanan.Pada proses 1.2 petugas koperasi melakukan input simpanan pada komputer berdasarkan SUM, dan pada proses 1.3 petugas koperasi mencetak buku anggota (BA). Setelah dicetak buku anggota dan SUM 3 rangkap di berikan ke bagian bendahara untuk ditandatangani. Proses 1.4 setelah ditandatangani oleh bendahara koperasi buku anggota (BA) dikembalikan ke anggota, SUM2 diarsip dalam arsip SUM dan SUM3 diberikan ke bagian pembukuan.

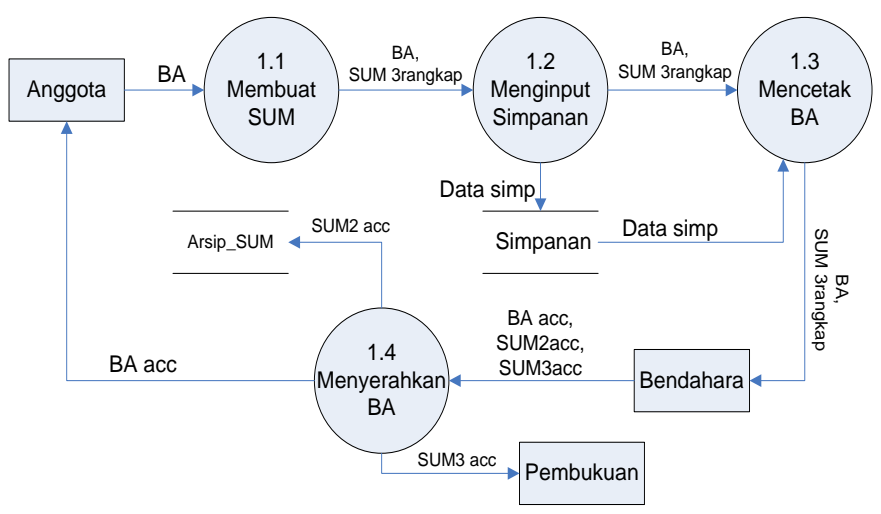

Gambar 5. Diagram Level 1 proses 1

\section{DFD Level 1 Proses 2}

Pada proses 2 anggota melakukan pengajuan pinjaman, membawa buku anggota (BA), kemudian petugas koperasi memberikan surat permohonan pinjaman (SPP) untuk diisi,setelah diisi SPP dikembalikan ke petugas koperasi. Selanjutnya BA dan SPP diberikan ke ketua untuk dianalisa kelayakan pemberian pinjaman. Pada proses 2.2 apabila telah disetujui BA dan SPP diberikan ke petugas koperasi dan keudian SPP diarsip dalam arsip SPP. Dalam proses 2.3 petugas koperasi membuat slip uang keluar(SUK) sebanyak 3rangkap dan membuat surat perjanjian pinjaman anggota. Pada proses 2.4 petugas koperasi melakukan input pinjaman berdasarkan SUK. Proses 2.5 petugas koperasi mencetak pinjaman dalam buku anggota. Kemudian BA, SPPA dan SUK 3 rangkap diberikan ke bendahara untuk ditandatangani. Proses 2.6 BA dan SPPA diberikan kepada anggota untuk ditandatangani dan mengembalikanya ke petugas koperasi. Petugas koperasi mengarsip SPPA dalam arsip SPP dan SUK2 dalam arsip SUK serta menyerahkan SUK3 kebagian pembukuan.

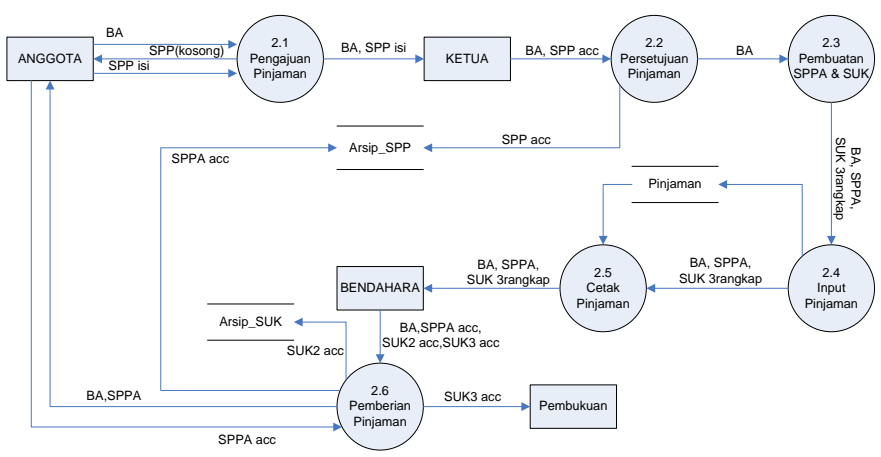

Gambar 6. Diagram Level 1 proses 2

\section{DFD level 1 proses 3}

Pada proses 3 petugas bendahara mencetak laporan simpanan berdasarkan data anggota dan data simpanan kemudian mengarsip pada arsip laporan serta memberikan laporan kepada ketua dan bendahara. Pada proses 3.2 petugas koperasi mencetak laporan pinjaman berdasarkan data anggota dan data pinjaman kemudian 
mengarsip dalam arsip laporan serta memberikan laporan pinjaman pada ketua dan bendahara.

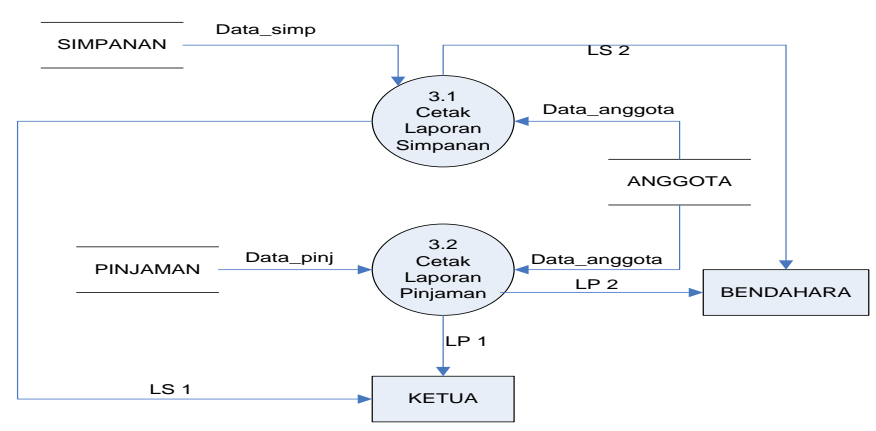

Gambar 7. Diagram Level 1 proses 3

\section{Entity Relationship Diagram (ERD)}

Entity Relationship Diagram atau diagram hubungan entitas dari sistem simpan pinjam yang diusulkan yang berfungsi untuk menggambarkan model basis data yang akan dipakai. Model basis data yang digunakan adalah basis data relational, dimana setiap entitas memiliki hubungan dengan entitas lain. Entitas dan hubungan yang digambarkan dalam model ERD tersebut nantinya akan dpakai untuk merancang basis data sistem simpan pinjam.ERD yang diusulkan dapat dilihat pada gambar 8 .

Penjelasan dari ERD sistem yang diusulkan, bahwa entitas anggota berelasi dengan entitas simpanan.Hubungan relasinya adalah one-tomany.Dimana setiap anggota memiliki banyak simpanan, tetapi tidak sebaliknya.Entitas anggota berelasi dengan entitas pinjaman.Hubungan relasinya adalah one-to-one. Dimana setiap anggota melakukan satu pinjaman begitupun sebaliknya.

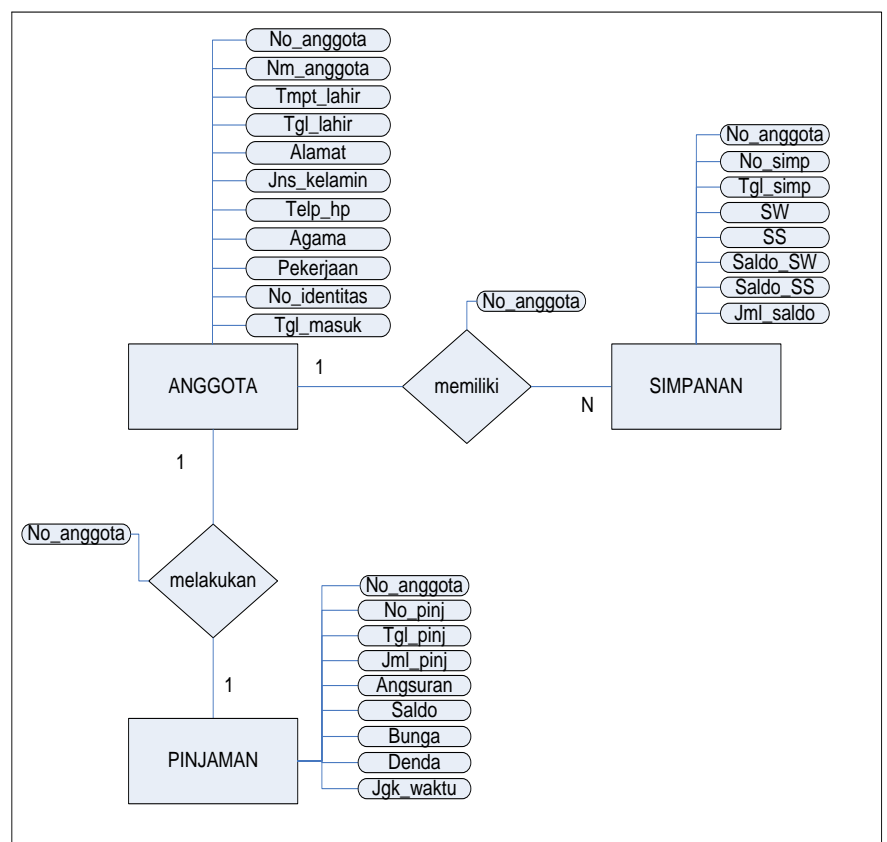

Gambar 8. Entity Relationship Diagram (ERD)

\section{Normalisasi}

Suatu file yang terdiri dari beberapa grup elemen yang berulang-ulang perlu diorganisasikan kembali. Proses untuk mengorganisasikan file untuk menghilangkan grup elemen yang berulang-ulang ini disebut dengan normalisasi. Berikut ini adalah tahapan dari normalisasi yang dilakukan yang dimulai dari keadaaan unnormalisasi, normalisasi $1 \mathrm{NF}$, normalisasi 2NF dan normalisasi 3NF.

Tabel 1. Tahap Normalisasi

\begin{tabular}{|c|c|c|}
\hline \multicolumn{3}{|c|}{ Tahap 1 UnNormalisasi } \\
\hline No_anggota & No_simp & Saldo \\
\hline Nm_anggota & Tgl_simp & Bunga \\
\hline Tmpt_lahir & SW & Denda \\
\hline Tgl_lahir & SS & Jngk_waktu \\
\hline Alamat & Saldo_SS & \\
\hline Jns_kelamin & Saldo_SW & \\
\hline Telp_hp & Jml_saldo & \\
\hline Agama & No_pinj & \\
\hline Pekerjaan & Tgl_pinj & \\
\hline No_identitas & Jml_pinj & \\
\hline Tgl_masuk & Angsuran & \\
\hline \multicolumn{3}{|c|}{ Tahap 2 Normalisasi 1NF } \\
\hline ANGGOTA & PINJAMAN & SIMPANAN \\
\hline No_anggota & No_pinj & No_simp \\
\hline Nm_anggota & No_anggota & No_anggota \\
\hline Tmpt_lahir & Tgl_pinj & Tgl_simp \\
\hline Tgl_lahir & Jml_pinj & SW \\
\hline Alamat & Angsuran & SS \\
\hline Jns_kelamin & Bunga & Saldo_SS \\
\hline Telp_hp & Jngk_waktu & Saldo_SW \\
\hline Agama & & Jml_saldo \\
\hline \multicolumn{3}{|l|}{ Pekerjaan } \\
\hline \multicolumn{3}{|l|}{ No_identitas } \\
\hline \multicolumn{3}{|l|}{ Tgl_masuk } \\
\hline \multicolumn{3}{|c|}{ Tahap 3 Normalisasi 2NF } \\
\hline ANGGOTA & SIMPANAN & PINJAMAN \\
\hline No_anggota $*$ & No_simp* & No_pinj* \\
\hline Nm_anggota & No_anggota** & No_anggota** \\
\hline Tmpt_lahir & Tgl_simp & Tgl_pinj \\
\hline Tgl_lahir & SW & Jml_pinj \\
\hline Alamat & SS & Angsuran \\
\hline Jns_kelamin & Saldo_SS & Bunga \\
\hline Telp_hp & Saldo_SW & Jngk_waktu \\
\hline Agama & Jml_saldo & \\
\hline \multicolumn{3}{|l|}{ Pekerjaan } \\
\hline \multicolumn{3}{|l|}{ No_identitas } \\
\hline \multicolumn{3}{|l|}{ Tgl_masuk } \\
\hline \multicolumn{3}{|c|}{ Tahap 4 Normalisasi 3NF } \\
\hline SIMPANAN & ANGGOTA & PINJAMAN \\
\hline No_simp* & No_anggota $*$ & No_pinj* \\
\hline No_anggota** & $\mathrm{Nm}$ anggota & No_anggota** \\
\hline Tgl_simp & Tmpt_lahir & Tgl_pinj \\
\hline SW & Tgl_lahir & Jml_pinj \\
\hline SS & Alamat & Angsuran \\
\hline Saldo_SS & Jns_kelamin & Bunga \\
\hline Saldo_SW & Telp_hp & Jngk_waktu \\
\hline \multirow[t]{4}{*}{ Jml_saldo } & Agama & \\
\hline & Pekerjaan & \\
\hline & No_identitas & \\
\hline & Tgl_masuk & \\
\hline
\end{tabular}




\section{Perancangan Database Sistem Yang Diusulkan}

Basis data (database) terdiri dari kumpulan file.

File database yang dibutuhkan dalam sistem akuntansi simpan pinjam seperti yang tampak di data flow diagram yang ditunjukkan pada tabel 2 .

Tabel 2. File Database Yang Dibtuhkan

\begin{tabular}{llll}
\hline \multicolumn{1}{c}{ Nama File } & Tipe File & Media File & Field Kunci \\
\hline Anggota & Induk & Harddisk & No_anggota \\
\hline Simpanan & Transaksi & Harddisk & No_simpanan \\
\hline Pinjaman & Transaksi & Harddisk & No_Pinjaman \\
\hline
\end{tabular}

Berikut ini adalah struktur dari file database diatas. Peneliti menggunakan file database untuk perancanangan sistem yang berisikan tabel anggota, simpanan anggota, sebagai berikut :

Tabel 3. Tabel Anggota

\begin{tabular}{clccc}
\hline No. & Field Name & Tipe & Size & Ket \\
\hline 1. & No_anggota & Text & 7 & Primary Key \\
\hline 2. & Nm_anggota & Text & 25 & \\
\hline 3. & Tmpt & Text & 15 & \\
\hline 4. & Tgl & Date/Time & 8 & \\
\hline 5. & Alamat & Text & 30 & \\
\hline 6. & Jns_kelamin & Text & 2 & \\
\hline 7. & Telp_hp & Number & 13 & \\
\hline 8. & Agama & Text & 10 & \\
\hline 9. & Pekerjaan & Text & 15 & \\
\hline 10. & No_identitas & Number & 16 & \\
\hline 11. & Tgl_masuk & Date/Time & 8 & \\
\hline & & & &
\end{tabular}

Adapun perancangan pengkodean pada primary key No_anggota yang digunakan peneliti adalah sebagai berikut:

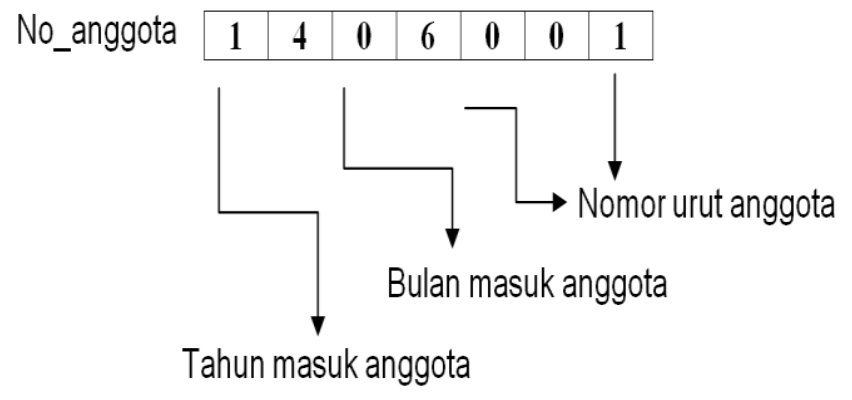

Tabel 4. Tabel Simpanan

\begin{tabular}{lllcl}
\hline No. & Field Name & Tipe & Size & Ket \\
\hline 1. & No_simp & Text & 9 & Primary key \\
\hline 2. & No_anggota & Text & 7 & Foreign key \\
\hline 3. & Tgl_simp & Date/Time & 8 & \\
\hline 4. & SW & Currency & 8 & \\
\hline 5. & SS & Currency & 8 & \\
\hline 6. & Saldo_SW & Currency & 8 & \\
\hline 7. & Saldo_SS & Currency & 8 & \\
\hline 8. & Jml_saldo & Currency & 8 & \\
\hline
\end{tabular}

Tabel 5. Tabel Pinjaman

\begin{tabular}{lllll}
\hline No. & $\begin{array}{l}\text { Field } \\
\text { Name }\end{array}$ & Tipe & Size & Keterangan \\
\hline 1. & No_pinj & Text & 9 & Primary Key \\
\hline 2. & No_anggota & Text & 7 & Foreign Key \\
\hline 3. & Tgl_pinj & Date/Time & 8 & \\
\hline 4. & Jml_pinj & Currency & 8 & \\
\hline 5. & Angsuran & Currency & 8 & \\
\hline 6. & Bunga & Currency & 8 & \\
\hline 7. & Jngk_waktu & Text & 2 & \\
\hline
\end{tabular}

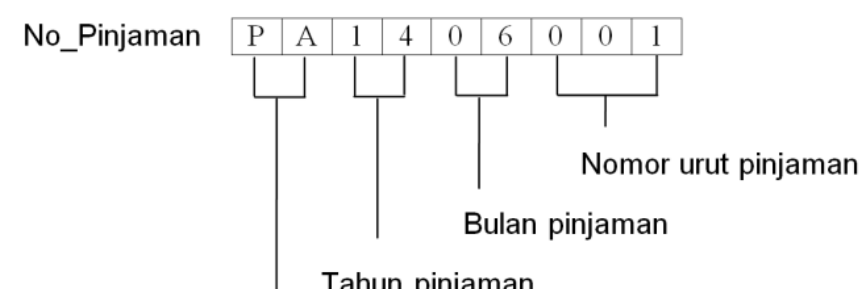

Kode pinjaman

Berdasarkan uraian analisis dan usulan usulan yang telah diuraikan maka, terdapat beberapa hal penting yang menjadi temuaan dalam yaitu analisis prosedur, analisis laporan dan analisis kebutuhan sistem. Pada hasil pengamatan pada analisis prosedur simpan pinjam pada Koperasi Dian Lestari Jakarta masih terdapat beberapa kekurangan. Hal ini dapat terlihat dalam pembuatan laporan simpanan dan laporan pinjaman yang hanya dibuat satu rangkap saja. Petugas koperasi hanya menunjukkan laporan tersebut kepada ketua dan bendahara untuk mengetahui saja dan kemudian diarsipkan oleh petugas koperasi. Dalam administrasi, diketahui bahwa ketua dan bendahara koperasi tidak melakukan pengarsipan atas laporan yang dikeluarkan oleh koperasi.

Arsip dalam prosedur simpan pinjam penting untuk dilakukan sampai pada jenjang ketua maupun bendahara koperasi. Hal ini nantinya dapat dijadikan sebagai evaluasi pengelolaan administrasi simpan pinjam serta mengawasi kelanjutan dari transaksi simpan pinjam yang dilakukan. Peneliti mengusulkan agar petugas koperasi juga memberikan laporan tersebut kepada bendahara dan pengawas, agar mereka dapat mengawasi kelanjutan dari adanya transaksi simpan pinjam yang dilakukan.

Selain itu dalam pebuatan SUM dan SUK juga tidak dibuat rangkap.Petugas koperasi hanya membuat masing - masing 1 dokumen saja. Hal ini dirasa kurang efektif karena bendahara sebagai pemegang keuangan tidak memiliki bukti atas keluar atau masuknya uang. Sehingga peneliti mengusulkan pembuatan SUM dan SUK yang dibuat rangkap dan diberikan kebendahara sebagai bukti uang masuk dan keluar.

Pada sisi laporan keuangan, dalam sistem lama hanya menghasilkan laporan simpanan dan laporan pinjaman, laporan ini dirasa cukup lengkap, tetapi dalam pembuatan laporan dengan sistem lama menghabiskan 
waktu cukup lama. Hal ini dikarenakan pengolahan data dan pembuatan laporanya masih dilakukan secara manual, sedangkan laporan dibutuhkan secara berkala untuk kepentingan manajemen dan diperlukan ketelitian tinggi. Kemungkinan kesalahan oleh operator (pekerja) atau human eror dalam pengelolaan data masih sangat besar karena masih menggunakan sistem manual. Selain itu terdapat kesulitan dalam pencarian data baik itu data anggota, simpanan maupun pinjaman.

Dari kelemahan-kelamhan pada laporan keuangan di Koperasi Kredit Dian Lestari tersebut, peneliti memberikan gagasan agar perusahaan menggunakan sistem simpan pinjam yang telah terkomputerisasi, tujuannya adalah agar laporan yang dihasilkan sistem dapat diandalkan karena datanya akurat, cepat dan lengkap.

Temuan dalam analisis kebutuhan sistem, pada dasarnya sistem manual atas simpan pinjam pada koperasi Dian Lestari Jakarta saat ini dinilai kurang memadai. Kesimpulan ini diambil karena terdapat beberapa kekurangan dan permasalahan dalam sistem. Oleh karena itu, koperasi membutuhkan solusi untuk mengatasi kekurangan dan permasalahan yang ada pada sistem simpan pinjam manual, yaitu dengan membuat sistem informasi akuntansi terkomputerisasi atas transaksi simpan pinjam. Kebutuhan sistem yang diperlukan koperasi adalah sebagai berikut :

a. Memerlukan suatu sistem informasi akuntasi simpan pinjam berbasis komputer yang mampu menyimpan, mengakses dan mengupdate data, serta meminimalisir terjadinya kesalahan dalam pemrosesan data. Sehingga sistem informasi akuntansi simpan pinjam yang dirancang memiliki kemampuan sebagai berikut:

1) Memproses data secara cepat dan menghasilkan informasi yang akurat bagi koperasi.

2) Mengurangi kesalahan dalam human eror.

3) Waktu yang dibutuhkan untuk memproses data lebih singkat dan akurat sehingga terjadi efisiensi waktu dan informasi dapat terjaga.

b. Sistem informasi akuntasi simpan pinjam yang terkomputerisasi akan mempermudah unit simpan pinjam ataupun bagian-bagian lain yang berwenang untuk mengetahui transaksi yang telah dilakukan, dokumen yang digunakan ataupun laporan yang dibutuhkan.

Dalam bagan alur dokumen simpan pinjam yang diusulkan peneliti, dapat dilihat penginputan dilakukan terlebih dahulu kedalam database, kemudian pengolahan data yang terkomputerisasi serta ketua yang mendapat rangkapan dari dokumen yang diperlukan dan melakukan pengarsipan atas dokumen, sedangkan dalam sistem simpan pinjam yang berjalan saat ini tidak dilakukan.

\section{SIMPULAN}

Perancangan sistem informasi akuntansi simpan pinjam yang dusulkan oleh peneliti dirancang untuk mampu mengatasi kelemahan dan kekurangan serta mampu memenuhi kebutuhan dari pengguna sistem. Perancangan sistem informasi akuntansi simpan pinjam tersebut menghasilkan beberapa file komputer yang nantinya dapat dicetak. Sistem informasi akuntansi simpan pinjam ini menyimpan serta mengolah data akuntansi dan memuat laporan, sistem informasi akutansi simpan pinjam yang diusulkan sudah memakai sistem yang terkomputerisasi. Peneliti membuat perancangan sistem informasi akuntansi simpan pinjam dengan menggunakan Microsoft visual basic 6.0, yang sebelumya telah dibuatkan desain sistem informasi akuntansi berupa Flowchart, DFD dan ERD rancangan tersebut dapat membantu unit simpan pinjam dalam mengolah data simpan pinjam.

Untuk mendukung kelancaran kinerja koperasi maka peneliti menyarankan beberapa hal yaitu, profesionalisme sumber daya manusia sangat dibutuhkan. Sumber daya manusia harus membekali diri dengan berbagai pengetahuan sehubungan dengan masalah pekerjaan yang ditekuni dan tentang komputer. Oleh karena itu, koperasi perlu mengadakan training untuk memperoleh sumber daya yang berwawasan dan terampil. DSeiring dengan bertambahnya anggota di waktu mendatang, koperasi membutuhkan sistem yang dapat mengatasi kelemahan dan kekurangan yang ada pada sistem yang dimiliknya serta mampu memenuhi kebutuhan dari kegiatan koperasi yang semakin meningkat. Maka diperlukan pengembangan sistem yaitu SIA yang lebih baik untuk memenuhi kebutuhan yang selalu berkembang seiring dengan perkembangan IPTEK, serta segera melakukan perbaikan apabila ditemukan kesalahan kerja pada sistem yang digunakan.

\section{DAFTAR PUSTAKA}

Baridwan, Z. (1996) Sistem Informasi Akuntansi. 2nd edn. Yogyakarta: BPFE Universitas Gajah Mada.

Daymon (2008) 'Metode-Metode Riset Kualitatif dalam Public Relations dan Marketing Communications'. Yogyakarta: Bentang Pustaka.

Fauzi, R. A. (2017) 'Sistem Informasi Akuntansi (Berbasis Akuntansi)', in Sistem Informasi Akuntansi (Berbasis Akuntansi).

Gayatri Mirza, Askardiya dan nurranto, H. (2019) 'Ekonomi Kerakyatan: Koperasi dan UMKM'. Unindra Press.

Limbong, B. (2010) Penusaha Koperasi Memperoleh Fondasi Ekonomi Rakyat.

Mulyadi (2001) edisi 3. Akuntansi manajemen, Konsep, Manfaat, dan Rekayasa., Universitas Gadjah Mada.

Ningsih, R. et al. (2020) 'Sistem Informasi Akuntansi Peminjaman Pada Koperasi Simpan Pinjam Tirta Mukti PDAM Bekasi', Jurnal Teknik Komputer. 
doi: 10.31294/jtk.v6i1.6823.

Puspita, N. R. (2018) 'Evaluasi Sistem Informasi Akuntansi Atas Prosedur Pengeluaran Kas Pada Koperasi Keluarga Besar Pt Semen Padang', Jurnal Ilmiah Manajemen Universitas Putera Batam.

Sugiyono, M. P. K. (2007) 'Kualitataif dan R\&D, Bandung: Alfabeta, 2010', Sugiyono, Metode Penelitian Kuantitatif kualitatif dan $R \& D$ Bandung: Alfabeta.

UU No 25 Tahun 1992 (1992) 'UU No 25 Tahun 1992', UU RI No 25 Tahun 1992 Tentang Perkoperasian. 